\title{
Література:
}

1. Шовкун Ю. Проблеми правового регулювання та визначення аквакультури. Підприємництво, господарство $і$ право. 2015. № 2 . С. 32-35.

2. Вдовенко Н.М. Рибне господарство України в умовах глобалізації економіки: [монографія]. К.: ЦП Компринт, 2016. 476 с.

3. Вдовенко Н. М. Нормативно-правове регулювання господарської діяльності у сфері аквакультури. Економічний форум. 2014. № 4. С. 4-12.

4. Велика українська юридична енциклопедія: Харків: Право, 2016. T. 14. Екологічне право. 2018. 776 с.

5. Краснова М. В. Компенсація шкоди за екологічним законодавством України (теоретико-правові аспекти): [монографія]. К. : 2008. 439 c.

6. Вдовенко Н. М. Державне регулювання розвитку аквакультури в Україні: К.: Кондор-Видавництво, 2013. 464 с.

7. Гетьман А. П., Шульга М. В., Анісімов Г. В., Соколова А.К. Екологічне право України в запитаннях та відповідях: навч. посіб. Х. : Одіссей, 2008. 480 с.

DOI https://doi.org/10.30525/978-9934-588-92-1-50

\section{СИСТЕМА ОРГАНІВ ДЕРЖАВНОГО РЕГУЛЮВАННЯ НА АГРАРНОМУ РИНКУ}

\author{
Павлюченко Ю. М. \\ кандидат юридичних наук, доиент, \\ доиент кафедри господарського права \\ Донеиького національного університету імені Василя Стуса \\ м. Вінниця, Украӥна
}

Ефективне функціонування аграрного ринку неможливе без державного регулювання.

Державне регулювання базується на нормах законодавства, якими закріплено органи державної влади та їх повноваження, проте систему органів регулювання аграрного ринку у законодавстві окремо не визначено.

У науці державному регулюванню аграрного ринку приділяли увагу B.М. Анікеєнко, С.В. Майстро, I.В. Охрименко, В.I. Семчик, Ю.О. Ульянченко, В.З Янчук та інші, проте це питання підлягає 
самостійному аналізу з огляду на останні зміни в системі органів державної влади.

Це підтверджує актуальність теми дослідження, яке спрямоване на конкретизацію система органів державного регулювання аграрного ринку.

За відсутності окремо закріпленого переліку органів регулювання аграрного ринку здійснити їх конкретизацію можливо на основі аналізу законодавства, положення якого закріплюють систему органів державної влади, визначають напрями державного регулювання та встановлюють особливості реалізації певної сільськогосподарської продукції.

Систему органів державного регулювання аграрного ринку на регіональному рівні представила В.М. Анікеєнко [1, с. 4], включивши до неї Верховну Раду України, Президента України, Кабінет Міністрів України та центральні органи виконавчої влади.

В аграрному праві подібним чином представляють систему органів державного регулювання сільського господарства, здійснюючи при цьому поділ на органи загальної та спеціальної компетенції. Погоджуючись, що до органів регулювання аграрного ринку загальної компетенції належать Верховна Рада України та Президент України, регулюючий вплив яких проявляється здебільшого у правотворчій діяльності, варто наголосити, що Кабінет Міністрів України має більш конкретні повноваження у цій сфері.

Так, Уряд наділено повноваженнями у сфері здійснення цінової політики (статті 3-5, 7 Закону України «Про державну підтримку сільського господарства України»). Згідно 3 цим Законом Кабінет Міністрів України наділений повноваженнями щодо запровадження режиму державних заставних закупівель зерна, надання кредитної субсидії, бюджетної тваринницької дотації, які впливають на товарне наповнення аграрного ринку та фінансовий стан його учасників. Повноваження Уряду щодо здійснення цінової політики також закріплено у законах України «Про молоко та молочні продукти», «Про зерно та ринок зерна в Україні» та інших; щодо загального регулювання ринку певної сільськогосподарської продукції, моніторингу аграрного ринку, сприяння розвитку інфраструктури аграрного ринку та інші випливають з законів України «Про Кабінет Міністрів України», «Про насіння і садивний матеріал», «Про основні принципи та вимоги до органічного виробництва, обігу та маркування органічної продукції».

Викликає інтерес пропозиція С. Майстро щодо введення посади віцепрем'єр-міністра з питань аграрної політики, сільського розвитку, екології та природокористування, яка обгрунтовується тим, що поєднання аграрної сфери 3 іншими сферами відповідальності вищих 206 
посадових осіб Уряду буде не на користь першої [2, с. 147]. Наразі аграрний сектор економіки в цілому та аграрний ринок, зокрема, не виділені як самостійний об'єкт діяльності Уряду. Такий висновок можна зробити після ознайомлення із структурою Кабінету Міністрів України та Програмою його діяльності від червня 2020 року, в якій регулювання аграрного ринку відображено у завданнях відповідного Міністерства [3].

В актах аграрного законодавства вказано центральний орган виконавчої влади, що забезпечує формування державної аграрної політики, або що формує та забезпечує реалізацію державної політики у сфері безпечності та основних показників якості харчових продуктів. Таким органом $є$ Міністерство розвитку економіки, торгівлі та сільського господарства [4]. Це Міністерство має широке коло завдань, реалізація деяких 3 них здійснює регулюючий вплив на аграрний ринок. Зокрема, реалізація заходів щодо розвитку інфраструктури аграрного ринку, проведення його моніторингу, видача дозвільних документів та інші. У структурі Міністерства $\epsilon$ директорати сільського розвитку та агропромислового розвитку, департамент аграрної політики та деякі інші підрозділи, рішення яких спрямовано на регулювання аграрного ринку.

Слід зазначити, що рішення про ліквідацію Міністерства аграрної політики та продовольства сприйняте суспільством неоднозначно [5]. Підтримуючи погляди щодо передчасності ліквідації Мінагрополітики, варто вказати, що на сучасному етапі, виходячи із стратегічного значення аграрного сектора для розвитку економіки, необхідності завершення основного етапу аграрних реформ, доцільно, щоб державне регулювання аграрного сектора й аграрного ринку здійснювало окреме міністерство.

Також після ліквідації Мінагрополітики не можна однозначно стверджувати про наявність органу державного регулювання із спеціальною компетенцією, оскільки з одного боку Міністерство розвитку економіки, торгівлі та сільського господарства має найбільш конкретні повноваження щодо державного регулювання аграрного сектора, а 3 іншого - перед сільським господарством об'єктами його відповідальності виступають економіка та торгівля.

Ще одним органом виступає центральний орган виконавчої влади, що формує та забезпечує реалізацію державної політики у сфері охорони здоров’я. Відповідно до ст. 6 Закону України «Про основні принципи та вимоги до безпечності та якості харчових продуктів» до його повноважень належить встановлення показників безпечності харчових продуктів та інших об'єктів санітарних заходів, дотримання яких $є$ прямою умовою допуску сільськогосподарської продукції на аграрний ринок. Наразі таким органом є Міністерство охорони здоров'я України. До системи органів державного регулювання аграрного ринку також 
потрібно віднести Державне агентство рибного господарства, яке забезпечує державне регулювання внутрішнього ринку рибної продукції, формування національного ринку вітчизняної продукції аквакультури здійснює моніторинг внутрішнього ринку рибної продукції [6].

При аналізі законодавства звертає на себе увагу різний підхід до викладу норм щодо органів державного регулювання. Так, поряд із законами, в яких закріплено повноваження вищеназваних органів, в інших ці органи виконавчої влади тільки названі (закони України «Про основні принципи та вимоги до безпечності та якості харчових продуктів», «Про бджільництво» та інші). Відповідно, якщо повноваження органів, які здійснюють державне регулювання аграрного ринку, закріплені у спеціальних законах, то це вимагає їх співставлення й узгодження з загальними повноваженнями цих органів, що впливає на здатність цих органів діяти послідовно, взаємоузгоджено та системно.

На місцевому рівні у складі обласних державних адміністрацій діє департамент агропромислового розвитку, до завдань якого входить забезпечення розвитку регіонального аграрного ринку та його інфраструктури, проведення моніторингу ринку та інші [7].

Отже, на підставі проведеного дослідження конкретизовано систему органів державного регулювання аграрного ринку. Доводиться, що всі органи, які складають систему органів державного регулювання аграрного ринку, є органами із загальною компетенцією, з яких Міністерство розвитку економіки, торгівлі та сільського господарства має найбільш конкретні повноваження щодо регулювання аграрного ринку.

\section{Література:}

1. Анікеєнко В.М. Інституційні засади державного регулювання аграрного ринку на регіональному ринку. Теорія $i$ практика державного управління. Вип. 2(29).

2. Майстро С. Удосконалення організаційно-інституційного механізму державного регулювання аграрного ринку. Державне управління та місиеве самоврядування: зб. наук. пр. /редкол.: С.М. Серьогін (голов. ред.) [та ін.]. Дніпропетровськ: ДРІДУ НАДУ. 2009. C. 144-152.

3. Програма діяльності Кабінету Міністрів України. Урядовий портал. URL: https://www.kmu.gov.ua/diyalnist/programa-diyalnostiuryadu

4. Положення про Міністерство розвитку економіки, торгівлі та сільського господарства: постанова Кабінету Міністрів України від 20 серпня 2014 р. № 459 (в редакції від 11 вересня 2019 року № 838). URL: https://zakon.rada.gov.ua/laws/show/459-2014-\%D0\%BF\#Text. 208 
5. Хворостяний В. Ліквідація Мінагрополітики - реакція ринку. Caŭm AgroPolit.com. 2019. 30 серпня. URL: https://agropolit.com/ spetsproekty/611-likvidatsiya-minagropolitiki--reaktsiya-rinku

6. Положення про державне агентство рибного господарства України: постанова Кабінету Міністрів від 30 вересня 2015 року № 895. URL: https://darg.gov.ua/_polozhennja_0_175_menu_0_1.html

7. Положення про департамент агропромислового розвитку Київської обласної державної адміністрації від 4 квітня 2018 року. URL: http://koda.gov.ua/normdoc/pro-zatverdzhennya-polozhennya-prodepar-28/ 